\title{
Contribution of Agriculture to Economic Growth in Mongolia
}

\author{
Dansranbavuu.L ${ }^{1}$, Natsagdorj. ${ }^{2}$, Tsolmon. $S^{3}$, Nasanjargal.P ${ }^{4}$, Scott.P. $H^{5}$ and \\ Enkhchimeg.Ts ${ }^{6}$ \\ ${ }^{1-6}$ Mandakh Burtgel University, Mongolia
}

\begin{abstract}
Background/Objectives: Despite the fact that Mongolia's real economy declined by $-1.3 \%$ in 2009 , it has actually increased by an average of $7 \%$ between 2000 and 2016. However, the real economic growth of the country has had an uneven impact on the lives of the people and the inequality in income is continually increasing. Methods/Statistical analysis: In recent years, many projects have been implemented to support SME's in order to increase production and create more jobs in Mongolia. Also some discounted loans have been provided for the same purpose. Unfortunately these large loans and other policy support have not been effective. This is evident due to the fact that the poverty rate has increased by 8 percentage points to $29.6 \%$ from 2014 to 2017 , and additionally, the unemployment rate went from $8.6 \%$ at the end of 2016 to $9.1 \%$ by the third quarter of 2017 , compared to the $7.8 \%$ rate which is where it was, at the end of 2013 . Foreign trade turnover was $\$ 11.1$ billion at the end of 2012, and dropped to $\$ 8.3$ billion by the end of 2016, which was a decrease of some $\$ 2.8$ billion, or $25.6 \%$. Findings: In this study, we will look into the contribution of the agricultural sector toward improving economic growth, Improvements/Applications: and we will propose some useful ideas to help develop the agricultural sector, including some innovations for creating more export-oriented jobs, in order to improve the real economic growth of the country, as whole
\end{abstract}

\section{Index Terms}

Agriculture, economic growth, economies of scale, globalization, export, Mongolia

Corresponding author : Enkhchimeg.Ts

enkhchimeg2002@must.edu.mn

- Manuscript received November 22, 2017.

- Revised December 6, 2017 ; Accepted December 8, 2017.

- Date of publication December 31, 2017.

(c) The Academic Society of Convergence Science Inc.

2546-1583 @ 2017 IJEMR. Personal use is permitted, but republication/redistribution requires IJEMR permission. 


\section{INTRODUCTION}

Stable and sustainable economic growth is a key factor in the improvement of people's living conditions, and their subsequent trust in the economy.

The Millennium Development Goals (MDG's) contains eight goals and eighteen targets, including reducing poverty, hunger and intensifying international cooperation, which were adopted in 2000 by the United Nations Millennium Summit, in order to strengthen the economy and improve livelihoods of the population [1]. The "Sustainable Development Goals", including 17 sub-goals, such as environmental changes, economic inequality, innovation and rational usage of natural resources, have already been successfully implemented, worldwide [2].

Recently, the Parliament of Mongolia created resolutions No.12 of 2008, of the State Great Hural (Parliament) of Mongolia [3] called the "Comprehensive National Development Strategy of Mongolia based on Millennium Development Goals", and resolution 19 of 2016, of the parliament [4] entitled, "Mongolia's Sustainable Development Concept-2030"

However, despite the adoption of the above policies, according to global development trends, there has been a lack of enforcement of these policies in actual practice.

Our research has considered how to increase per capita GDP, improve labor productivity per capita, and how to introduce innovation into non-mining industries; especially how to improve innovation in the agricultural sector, and foreign trade by selling technologically advanced products to international markets.

Economic Development, Globalization, Agricultural clusters, and Foreign Trade

In recent years, how to clearly define what is considered economic development, and how to identify competitive advantages, and harmonize the development of the country with globalization, and also how to effectively use foreign trade in the development of the country has been often debated by economists. Ultimately, the only way to achieve these goals is with effective partnership of various companies, or a "cluster-based policy" [5].

\section{A. Economic Development}

In order to measure the growth of the country and to compare the average growth rates between the different regions, one theory is to divide the economy of the country into "domestic consumption" and "exports" [6]. According this theory, exports become the foundation for regional economic development, and a means for developing employment which supports the creation of these exports. Economic endeavors and companies which are associated with the export sector, also have the potential to create strong multiplier effects for other companies in other sectors. As the result, all sectors can be benefited both directly, and indirectly[7].

Some scholars have defined sustainable development as being when the average level of future generations' quality of life, does not decrease from the current levels [8]. And they have defined inclusive development as being when all members of a society have the right to equitable social welfare [9].

Throughout the history of Asia, sustainable economic growth has been important for improving the living standards of citizens, as it increases the number of middle-income people, thereby reducing poverty. So economic growth is important, and improving accessibility to it is necessary for enhancing the general social welfare [10].

Some researchers have defined inclusive growth as growth which covers a variety of sectors of the economy (broad based growth), and which also shares its benefits to the members of the society (shared growth) [11]. Rapid and sustained poverty reduction requires inclusive growth which allows people to both contribute to and to benefit from economic the growth (OECD). In Mongolia, before anything else, we need to try to develop the agricultural and food processing industries, as well as other potential labor inclusive industries.

\section{B. Globalization}

Globalization is affecting the world economy and competitiveness between exporting nations, more and more with each passing year. In order to remain competitive, both domestic and international companies need to compete with local competitors, as well as worldwide competitors, who might produce similar, or substitute products. The accelerating growth of information technology, and logistics make it increasingly more challenging to stay competitive. The global economy is not just a challenging obstacle, it can also give us unprecedented opportunities to expand our markets [12].

Some countries, such as China, Hong Kong, Singapore, Taiwan, and South Korea, have all competed successfully in global markets. Intensified production capacity and their real GDP grew by nearly 8-10 percent per year, every year since the 1980s. From 1965-1980, the real GDP of Latin 
American countries grew by nearly 6 percent annually. But since entering global markets, their average growth rates have fallen to 1.6 percent since the 1980's.

The problems Latin America has faced with development compared to the policies of East Asian countries are as follows:

1) Latin American countries had used more foreign loans simply to cover budget deficits, and not for the purposes of creating future revenue generation.

2) Their loan policy to support production was mostly directed to import substitution sectors, rather than export-oriented sectors. After all, Latin American countries have experienced a huge foreign debt burden since the 1980s, whereas the foreign debt repayment was started, and conversely, the economic growth slowed down.

And 3) Since the 1970's and into the 1980's, a lot of Latin countries were ravaged by civil wars, which Asian countries did not suffer [13].

To use globaization successfully, while trying to avoid repeating the failed policies of Latin American countries, in which their governments generally tried to implement and support import-substitiuing sectors, rather than export-oriented sectors, can be compared to the economies of scale.

In 1977, J.Panzar and R. Wills established the unit cost reduction ideas expanding the quantity of output [14]. Their ideas are mainly based on novels and ideas of A. Smith and K. Marx

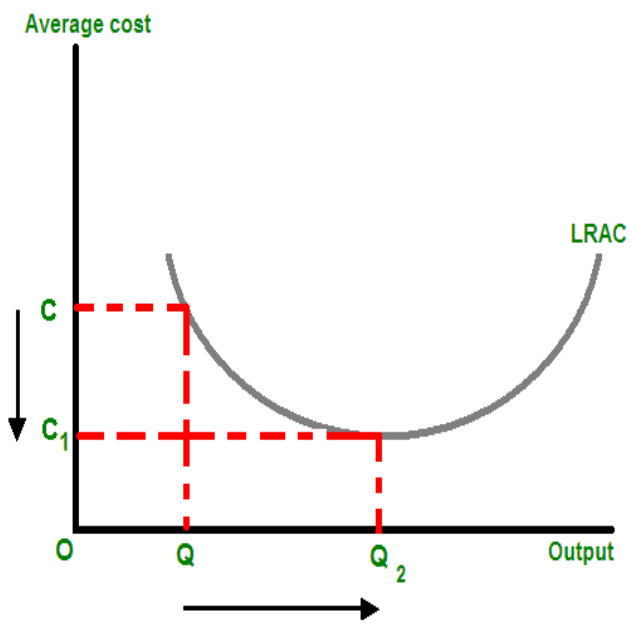

Figure 1. Economies of scale

Source: www.wikipedia.org
In the long run, the unit cost of the products, which if manufactured small amounts, will ultimately be higher than the unit cost of the end products, which is close to the optimal amount of production (around of Q2). But to compete globally, they must compete with the production quantities of the other major exporting countries. For example, clothes that are produced in Mongolia only for domestic consumption by its 3 million citizens, will cost more than clothes, whcih are manufactured in a foreign country such as Vietnam, Bangladesh and China, which are for the purpose of exporting to a gloabal market.

The recommended development policy for Mongolia, is to create products, services and clusters, which can compete in terms of quality and unit costs, on global markets, especially in agriculture, using the public-private partnerships.

\section{Agricultural clusters}

Clusters are broadly defined as "a geographical integration of factories, which create advantages through their close location" [15]. Clusters can also be defined as "a geo-integration of companies and institutions associated with each other in a particular business sector" by Porter [16], which is essentially the same thing. In other words, and more simply, they are a group of related businesses that are in a close geographical area, thereby providing a logistical advantage.

There is enormous potential for development opportunity in the agricultural sector within most developing countries. We need to remember that in highly developed countries the agricultural sector is also well developed. However, in developing countries, it's common for the poverty level of employees in the sector to be high with a low average income compared to other sectors.

Agricultural sector clusters can be categorized as follows: First, that the global supply chain is influenced by regional development. Second, that the Agricultural Business Complex refers to all interrelated activities required to produce and market a particular kind of agricultural product, and that the members of the complex are always dependent on others [17]. Third, the agricultural production park is a multi-purpose complex that can provide agricultural production companies an advantage with cutting costs for some related services, such as transportation, warehousing, packaging; etc. Fourth, that export zones of agricultural products are defined as clusters in order to increase agricultural only exports. Fifth, that the agricultural product and food 
export consortium combines all related SME's into itself, while always committing to collecting products and services of member SME's in order to market these products overseas, collectively [18]. Sixth, That the "One Village-One Product" method, which originated in Japan, where one village concentrates all its industry into one product, and improves it by marketing and additional product development support. Seventh, that the Subnational Innovation Systems are differentiated according to boundaries within production clusters. For example, innovation systems of a country are often separated by administrative boundaries [19].

Success stories of agricultural clusters are Chilean and Malaysian cases. At the beginning of development, these countries relied on the mining industry and gradually became big producers of expensive agricultural products, which created increasing demands. The experiences of these two countries show that the government can play an important role in developing industrial clusters through supporting infrastructure, providing business services, and technology and export assistance, as well as subverting some logistical, or boundary issues, and by offering tax incentives [20].

\section{Current situation of Mongolia's economy}

In recent years, especially from neighboring China, demand for raw minerals has been decreasing and commodity prices have been dropping as well. This has put an even greater burden on Mongolian revenues, forcing them to rely more on foreign loans, and subsequently reducing general economic growth.

From 2010-2016, Mongolia's real GDP increased from 9.8 trillion $\mathrm{MNT}$, to 16.0 trillion $\mathrm{MNT}$; representing an increase of 63.3 percent during that period.

According to data from the Ministry of Finance, the gross budget revenues for the Mongolian Government had dropped to 5,852.1 billion MNT by the end of 2016, representing a decrease of some 131.3 billion MNT, or 2.2 percent from the previous year.

The main reasons for this decline in general revenues are a combination of both macroeconomic conditions, particularly the general global economic slowdown of 1.4 points year on year from 2015, the valuation of the US Dollar, and the volume decline of both imports and exports, and the gross mismanagement of some local financial institutions, compounded by a subsequently significant decrease in revenues from FDI.

It required the GoM to make budget expenditures on an emergency basis, which caused the delay in financing some public services, and construction projects the next fiscal year.

Private businesses greatly reduced the number of their employees and the volume of debt that was dependant on Governemnt payments became overextended as most of these payments were delayed. As a result, it is clear that Mongolia's economy is in a current state of crisis, essentially due to general fiscal mismanagement, and wild fluctuations of commodity mineral prices.

In order to correct these policy mistakes and to create new, sustainable fiscal revenue sources, the Government of Mongolia has been working on improving the legal environment to support SMEs, granting discounted loans, and providing some advantages to domestic producers for budget procurement. As a result of the policy change, over 53 thousand SMEs were operating nationwide by the end of 2016.

More than 80 percent of these SMEs had 1-9 employees, while the government provided 745.5 billion MNT to SMEs between 2009-2016 [21].

While the world average percentage of foreign trade in GDP is $29.4 \%$, the ratio in Mongolia is $50.8 \%$. Despite this high rate in relation to the world average, $71.0-89.2 \%$ of Mongolia's total exports are of only mining products, and this percentage is unlikely to decrease in the upcoming years.

This is currently the biggest risk for Mongolia's fiscal revenue sustainibility, as their economy continues to depend on the volatile market price of minerals.

Table 1. SOME INDICATORS OF MONGOLIAN FOREIGN TRADE, MILLION USD

$\begin{array}{clllll}\text { Indicators } & 2012 & 2013 & 2014 & 2015 & 2016 \\ \begin{array}{c}\text { Gross } \\ \text { turnover }\end{array} & 11,123.0 & 10,626.9 & 11,011.0 & 8,466.8 & 8,274.5 \\ \text { Exports } & 4,384.7 & 4,269.1 & 5,774.3 & 4,669.3 & 4,916.3 \\ \text { Imports } & 6,738.4 & 6,357.8 & 5,236.7 & 3,797.5 & 3,358.1 \\ \begin{array}{c}\text { Trade } \\ \text { balance }\end{array} & -2,353.7 & -2,088.8 & 539.2 & 871.8 & 1,558.2 \\ \begin{array}{c}\text { Mining } \\ \text { exports }\end{array} & 3,909.6 & 3,495.5 & 4,791.5 & 3,678.2 & 3,484.1\end{array}$

Source: National Statistical Office of Mongolia

\section{RESEARCH METHODOLOGY}

We used the multiple regression analysis (OLS 


\begin{tabular}{|l|l|l|l|l|l|l|l|l|l|}
\hline & RGDP & RAGDP & EXPT & IMPT & FDI & GDPCBP & INFRAT & EXCRAT & OPNSS \\
\hline Mean & 6.1 & 3.7 & 2025.7 & 2248.0 & 1244384 & 7233277 & 15.5 & 1185.9 & 86.6 \\
\hline Median & 6.4 & 4.7 & 1063.9 & 1177.3 & 394494 & 3041406 & 10.0 & 1170.4 & 87.8 \\
\hline Maximum & 17.3 & 21.1 & 5774.3 & $6738.4 \mathrm{~s}$ & 6466350 & 23935854 & 66.3 & 2145.5 & 109.7 \\
\hline Minimum & -1.3 & -19.2 & 356.1 & 258.4 & 30100 & 382103 & 1.1 & 409.3 & 61.1 \\
\hline Std. Dev. & 4.4 & 10.9 & 1842.1 & 2167.8 & 1819903 & 8173387 & 16.8 & 429.9 & 12.1 \\
\hline Skewness & 0.6 & -0.6 & 0.8 & 1.0 & 1.9 & 1.0 & 1.9 & 0.3 & -0.5 \\
\hline Kurtosis & 3.0 & 2.9 & 2.0 & 2.7 & 5.6 & 2.5 & 5.7 & 3.2 & 2.9 \\
\hline Jarque-Bera & 1.3 & 1.6 & 3.2 & 4.0 & 20.4 & 4.4 & 21.2 & 0.3 & 0.9 \\
\hline Probability & 0.5 & 0.5 & 0.2 & 0.1 & 0.0 & 0.1 & 0.0 & 0.9 & 0.6 \\
\hline
\end{tabular}

method) and granger causality tests based on the collaborative research of Kehinde and other researchers [22].

Adding to the following factors of the research of the Nigerian case study, the real GDP growth of the agriculture sector is used in our study:

\section{Dependent variable:}

RGDP- Real GDP growth, by percentage

\section{Independent variables:}

RAGDP- Real agricultural GDP growth, by percentage

EXPT- Gross exports, by million USD

IMPT- Imports, by million USD

FDI- Foreign Direct Investments, by million MNT GDPCBP- Nominal GDP, by million MNT

INFRAT - Inflation rate, by percentage

EXCRAT- Tugrik's exchange rate compared to USD

\section{RESEARCH RESULTS}

Table 2 shows statistical findings for the last 23 years of the factors surveyed. For example, the real GDP growth was the highest in 2011, (17.3\%), and the lowest in $2009,(-1.3 \%)$. During the observation period, the real GDP grew at average $6.1 \%$ annually. Seeing that the standard deviation of the growth is $4.4 \%$, we can say that the growth rate is considered to be in the "high volatile" range.

Table 2. Definitive STATISTIC OF VARIABLES, 1994-2016.

\section{Source: Calculations by researchers}

Whenever a time series data is used, it is necessary to check whether it is stable or not, and the researchers are primarily screened by the Augmented Dickey-Fuller test. The factors used in this study, except the real growth (RAGDP) are evaluated as instable at normal levels. These factors became stable at a 90-95\% significant level of the 1 st difference.

As regards to the regression results, there are positive relationships between the real GDP growth and foreign direct investment growth (lagging for 1 year) and the real agricultural GDP growth. Then there are negative relationships between the the real GDP growth and the tugrik's exchange rate against the US dollar, and the 1 year lagged value of real economic growth. While other variables are not strongly affected, the economic openness indicator has positive effects at an $89 \%$ significance level.

Our research has very similar results with the results of Kehinde's studies in Nigeria. The main difference is that the inflation rate (INFRAT) does not affect the real economic growth of our country, but the real agricultural GDP growth (RAGDP), which has been added to our study, has a strong and positive impact on the real GDP growth. We tested the reliability of the regression model and the results are included in the appendix.

According to the applied Jarque-Bera test, the statistics are 0.26 , whereas the probability of a normal distribution of $87.7 \%$ to verify that the residual value has a normal distribution (appendix 1), and the $\mathrm{Q}$ statistical test is to determine that the autocorrelation effects of the residual variables doesn't have any significant correlation with previous periods (appendix 2). The F statistics of Breusch-Godfrey's LM test to check whether there exists a serial correlation, or not, is 0.49 , or a probability of $62.4 \%$ (The serial correlation also 
doesn't exist) (table 3).

Table 3. Augmented Dickey FulLER TEST RESUlt

\begin{tabular}{|l|c|c|c|c|c|}
\hline \multirow{2}{*}{ Variables } & \multicolumn{2}{|c|}{ ADF test result } & \multicolumn{2}{c|}{ Critical value, Prob.* } & \multirow{2}{*}{ Lag length } \\
\cline { 2 - 5 } & Level & First difference & Level & First difference & I 1$)$ \\
\hline RGDP & -2.639351 & -4.381151 & 0.1005 & $0.0029^{* * *}$ & $\mathrm{I}(0)$ \\
\hline RAGDP & -3.182401 & -3.805269 & $0.0356^{* *}$ & $0.0096^{* * *}$ & $\mathrm{I}$ \\
\hline EXPT & 0.121350 & -4.163426 & 0.9587 & $0.0063^{* * *}$ & $\mathrm{I}(1)$ \\
\hline IMPT & -1.148355 & -3.333963 & 0.6772 & $0.0261^{* *}$ & $\mathrm{I}(1)$ \\
\hline FDI & -1.249540 & -4.622439 & 0.6314 & $0.0018^{* * *}$ & $\mathrm{I}(1)$ \\
\hline GDPCBP & 0.158410 & -6.163214 & 0.9627 & $0.0001^{* * *}$ & $\mathrm{I}(1)$ \\
\hline INFRAT & -1.148355 & -3.333963 & 0.6772 & $0.0261^{* *}$ & $\mathrm{I}(1)$ \\
\hline EXCRAT & 0.237266 & -3.467659 & 0.9687 & $0.0198^{* *}$ & $\mathrm{I}(1)$ \\
\hline OPNSS & -2.300555 & -5.060108 & 0.1817 & $0.0007^{* * *}$ & $\mathrm{I}(1)$ \\
\hline
\end{tabular}

*MacKinnon (1996) one-sided p-values.

Source: Calculations by researchers

Table 4. REGRESSION RESULTS /OLS METHOD/

\begin{tabular}{ccccc}
\hline \hline Variable & Coefficient & Std. Error & t-Statistic & Prob. \\
C & 28.74784 & 29.32982 & 0.980157 & 0.3464 \\
RAGDP & 0.216374 & 0.068952 & 3.138034 & 0.0086 \\
LOG(EXPT) & 2.883290 & 5.264288 & 0.547708 & 0.5939 \\
LOG(IMPT) & 2.940321 & 4.927672 & 0.596696 & 0.5618 \\
LOG(FDI(-1)) & 3.033832 & 1.509887 & 2.009310 & 0.0675 \\
LOG(GDPCBP) & -6.796238 & 4.528091 & -1.500906 & 0.1592 \\
LOG(INFRAT) & 0.240051 & 0.848779 & 0.282819 & 0.7821 \\
D(EXCRAT) & -0.022726 & 0.005642 & -4.028038 & 0.0017 \\
D(OPNSS) & 0.085562 & 0.049976 & 1.712051 & 0.1126 \\
RGDP(-1) & -1.106691 & 0.236797 & -4.673584 & 0.0005 \\
\hline \hline
\end{tabular}

Explanations: $* * *=1 \%-, * *=5 \%, *=10 \%$ significance level R2 = 0.907514; Adj. R2 = 0.838149; F-statistics = 13.08323; Prob $($ F-statistic $)=0.000063 ;$ DW stat $=1.823714$;

$\mathrm{D}(\mathrm{RGDP})=28.7478431155+0.216373528906 * \mathrm{RAGDP}+$ $2.88328997351 *$ LOG $($ EXPT $)+2.9403212574 *$ LOG(IMPT) + $3.03383166291 *$ LOG(FDI(-1)) - 6.79623809865*LOG(GDPCBP) $+0.240050962323 *$ LOG(INFRAT) $0.022725813931 * \mathrm{D}($ EXCRAT $)+0.0855621952728 * \mathrm{D}(\mathrm{OPNSS})-$ $1.10669093856 *$ RGDP(-1)

The F statistics of the Breisch-Pagan-Godfrey test to check the heteroscedasticity is 0.9158 , and its probability is $0.54 \%$ (table 4 ). The above tests show that our estimated OLS model is a statistically significant.
Finally, we evaluated the long-term correlation between these parameters using the Cointegration (Johansen \& Juselius, 1990) and the Granger causal test. According to the cointegration test, a long-term relationship may exist between these factors.

However, the results from the Granger test show that the actual growth of real GDP becomes the Granger cause relevant to the real agricultural GDP growth $(\mathrm{F}$ stat $=19.8798$, prob $=0.0003)$, and the exchange rate becomes the Granger cause on the real agricultural GDP growth rate, which is also (F stat $=$ 9.24635 , prob $=0.0070)$. In other words, real GDP growth and exchange rates, affect the real growth of the agricultural sector after the first year.

Because this effect is monitored for last two years, we can say that a change in foreign investment is 
likely to have a strong impact on real GDP growth after the next two years $(\mathrm{F}$ stat $=2.91686$, prob $=$ 0.0832).

\section{CONCLUSION AND RECOMMENDATION}

Most developed countries today were originally based largely on agriculture during their early stages of development, and since agriculture is one of the most labor intensive sectors, this created many jobs with a comparatively minimal investment.

This research was begun with a preliminary hypothesis that the current SME policies in Mongolia are not effective at reducing social effectiveness and divides the potential financial sources into too many small, individual pieces.

The study was based on the collaborative research of Kehinde and other researchers using the OLS method and Granger test methods (Kehinde, Jubril, Felix, \& Edun, 2012).

We have added the real agricultural GDP growth to the variables used in the previous studies of Kehinde; etc, and both the real agricultural GDP growth of Mongolia (RAGDP), and the previous year's FDI (LOG (FDI (-1)), which have both a strong and positive impact on the real economic growth.

Furthermore, ensuring a growth of FDI and real agricultural GDP at same time, as well as promoting agricultural clusters oriented to global markets(can be closer to the economies of scale), subsidized with substantial government support, will be helpful in creating new jobs, reducing poverty, building an effective middle class, and accelerating real GDP growth in the future sustainably.

In other words, Mongolia needs to focus on its relative advantages, especially based on the agricultural sector, and must concentrate on developing a few other sectors, which can produce the desired export-oriented products at closer levels to the economies of scale.

\section{REFERENCES}

[1] UN. (2000). Millenium Development Goals. Washington: The United Nations. www.un.org/millenniumgoals

[2] UN. (2015). Sustainable Development Goals. Washington: The United Nations. http://www.unfoundation.org/features/globalgoals/theglobal-goals.html

[3] УИХ. (2008). Монгол Улсын мянганы хөгжлийн зорилтод суурилсан үндэсний хөгжлийн цогц бодлого. Улаанбаатар: УИХ-ын тогтоол.

[4] УИХ. (2016). Монгол Улсын тогтвортой хөгжлийн үзэл баримтлал-2030. Улаанбаатар: УИХ-ын тогтоол.
[5] Enright, M. J., \& Ffowcs-Williams, I. (2002). Local partnerships, clusters and SME globalization. Enhancing SME Competitiveness.

[6] Isard, W., \& Isard, P. (1965). General Social, Political and Economic Equilibrium for a System of Regions. Regional Science Association.

[7] Szajnowska-Wysocka, A. (2009). Theories of regional and local development-abridged review. Bulletin of Geography. Socio-economic series, 12(12), 75-90.

[8] Dasgupta, P. (2007). Measuring sustainable development: theory and application. Asian Development Review, 24(1), 1.

[9] Ali, I., \& Son, H. H. (2007). Measuring inclusive growth. Asian Development Review, 24(1), 11.

[10] Л.Дансранбавуу, Б. Г. (2017). Орон нутгийн өсөлт, түҮний боломжууд. МУИС-ийн Орхон ИС.

[11] World Bank. (2009). What is Inclusive Growth? Washington: World http://siteresources.worldbank.org/INTDEBTDEPT/Resourc es/4689801218567884549/WhatIsInclusiveGrowth20081230.pdf

[12] Л.Дансранбавуу. (2017). 21 дүгээр зууны эдийн засагт анхаарах зүйлс,. Хэрэглээний эдийн засаг сэтгүүл, Улаанбаатар.

[13] Singh, A. (1993). Asian economic success and Latin American failure in the 1980s: new analyses and future policy implications. International Review of Applied Economics, 7(3), 267-289.

[14] Panzar, J. C., \& Willig, R. D. (1977). Economies of scale in multi-output production. The Quarterly Journal of Economics, 481-493.

[15] Bosworth, B., \& Broun, D. (1996). Connect the dots: using cluster-based strategies to create urban employment. Firm Connections, 4(2), 1-6.

[16] Porter, M. E. (1998). Clusters and the new economics of competition (Vol. 76, No. 6, pp. 77-90). Boston: Harvard Business Review.

[17] Simons, A. E., Hoogerwerf, A., \& Reinders, M. P. (1992). Management of agribusiness complexes. In European Workshop on Integrated Systems in Agricultural Informatics, Bonn (Germany), 13-14 Feb 1992. ILB.

[18] UNIDO. (2003). Development of clusters and networks of SMEs: The UNIDO programme. A guide to export consortia. . Vienna: United Nations Industrial Development Organization.

[19] Galvez-Nogales, E. (2010). Agro-based clusters in developing countries: staying competitive in a globalized economy. Agricultural Management, Marketing and Finance Occasional Paper (FAO)

[20] Kjoellerstroem, M. (2007). Agro-based industries and growth: prospects for Sub-Saharan Africa. Sustainable Development Innovation Briefs, 3.

[21] ХХААХYЯ. (2017). Жижиг, дунд үйлдвэрийн тухай хуулийн хэрэгжилттэй холбоотой асуудлаар хийсэн мэдээлэл. Улаанбаатар: XXАAXYЯ.

[22] Kehinde, A. O., Jubril, A. O., \& Felix, A. O. (2012). Foreign trade and economic growth in Nigeria: An empirical analysis. American Academic \& Scholarly Research Journal, 4(5), 1. 
International Journal of Emerging Multidisciplinary Research 2017 Dec. 1(2):23-32 


\section{ATTACHMENTS}

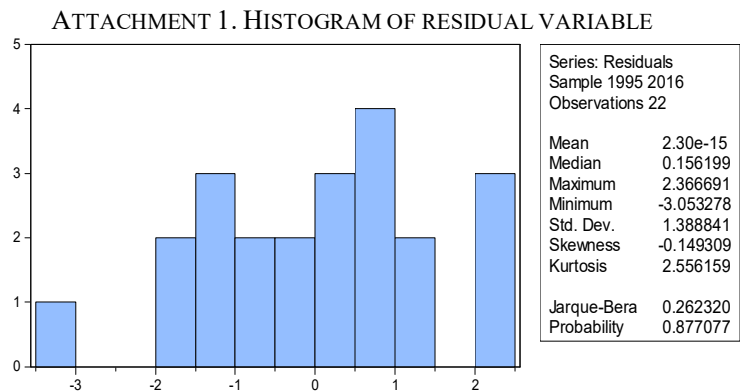

ATTACHMENT 2. THE AUTOCORRELATION ANALYSIS OF RESIDUAL VARIABLES

Date: $12 / 07 / 17$ Time: 13:12

Sample: 19942016

Included observations: 22

Q-statistic probabilities adjusted for 9 dynamic repressors

\begin{tabular}{|c|c|c|c|c|c|c|}
\hline Autocorrelation & Partial Correlation & & $\mathrm{AC}$ & PAC & Q-Stat & Prob* \\
\hline$\cdot|\cdot|$ &.$|\cdot|$ & 1 & 0.010 & 0.010 & 0.0025 & 0.960 \\
\hline$\left.\cdot\right|^{*} \cdot \mid$ & $\cdot|* \cdot|$ & 2 & 0.174 & 0.174 & 0.8053 & 0.669 \\
\hline$* * \mid$ & $*|\cdot|$ & 3 & -0.172 & -0.180 & 1.6245 & 0.654 \\
\hline$* *|\cdot|$ & $*^{* *} \cdot \mid$ & 4 & -0.222 & -0.260 & 3.0719 & 0.546 \\
\hline$* * *||$. & $* * *||$. & 5 & -0.446 & -0.432 & 9.2507 & 0.099 \\
\hline$\cdot *|\cdot|$ & $* *|\cdot|$ & 6 & -0.189 & -0.242 & 10.429 & 0.108 \\
\hline.$||$. &.$|\cdot|$ & 7 & -0.043 & -0.037 & 10.495 & 0.162 \\
\hline$* * \mid$ & $\cdot * *|\cdot|$ & 8 & -0.067 & -0.292 & 10.666 & 0.221 \\
\hline.$|* *|$. & $*|\cdot|$ & 9 & 0.270 & -0.082 & 13.632 & 0.136 \\
\hline$\left.\cdot\right|^{*} \cdot \mid$ & $*|\cdot|$ & 10 & 0.153 & -0.160 & 14.658 & 0.145 \\
\hline$\left.\cdot\right|^{*} \cdot \mid$ & $* *|\cdot|$ & 11 & 0.141 & -0.242 & 15.617 & 0.156 \\
\hline.$|*|$ &.$||$. & 12 & 0.181 & 0.038 & 17.347 & 0.137 \\
\hline
\end{tabular}

*Probabilities may not be valid for this equation specification. 
ATTACHMENT 3.

Breusch-Godfrey Serial Correlation LM Test:

\begin{tabular}{|c|c|c|c|}
\hline F-statistic & 0.494632 & Prob. F $(2,10)$ & 0.6240 \\
\hline Obs*R-squared & 1.980463 & Prob. Chi-Square(2) & 0.3715 \\
\hline
\end{tabular}

Test Equation:

Dependent Variable: RESID

Method: Least Squares

Date: 12/07/17 Time: 13:13

Sample: 19952016

Included observations: 22

Presample missing value lagged residuals set to zero.

\begin{tabular}{|c|c|c|c|c|}
\hline Variable & Coefficient & Std. Error & t-Statistic & Prob. \\
\hline $\mathrm{C}$ & 17.34394 & 35.53301 & 0.488108 & 0.6360 \\
\hline RAGDP & -0.053471 & 0.089918 & -0.594664 & 0.5653 \\
\hline LOG(EXPT) & 1.331649 & 5.662010 & 0.235190 & 0.8188 \\
\hline LOG(IMPT) & 2.259594 & 5.848185 & 0.386375 & 0.7073 \\
\hline LOG(FDI(-1)) & -0.030098 & 1.578116 & -0.019072 & 0.9852 \\
\hline LOG(GDPCBP) & -2.801393 & 5.594903 & -0.500704 & 0.6274 \\
\hline LOG(INFRAT) & -0.430219 & 0.987837 & -0.435516 & 0.6724 \\
\hline $\mathrm{D}(\mathrm{EXCRAT})$ & 0.002385 & 0.006782 & 0.351631 & 0.7324 \\
\hline $\mathrm{D}(\mathrm{OPNSS})$ & -0.015965 & 0.054660 & -0.292073 & 0.7762 \\
\hline RGDP(-1) & 0.049320 & 0.275273 & 0.179166 & 0.8614 \\
\hline RESID(-1) & 0.120985 & 0.415753 & 0.291003 & 0.7770 \\
\hline $\operatorname{RESID}(-2)$ & 0.509250 & 0.512519 & 0.993622 & 0.3438 \\
\hline R-squared & 0.090021 & Mean dependent var & & $2.30 \mathrm{E}-15$ \\
\hline Adjusted R-squared & -0.910956 & S.D. dependent var & & 1.388841 \\
\hline S.E. of regression & 1.919897 & Akaike info criterion & & 4.444872 \\
\hline Sum squared resid & 36.86005 & Schwarz criterion & & 5.039986 \\
\hline Log likelihood & -36.89359 & Hannan-Quinn criter. & & 4.585063 \\
\hline F-statistic & 0.089933 & Durbin-Watson stat & & 1.818765 \\
\hline Prob(F-statistic) & 0.999788 & & & \\
\hline
\end{tabular}


ATTACHMENT 4.

Heteroskedasticity Test: Breusch-Pagan-Godfrey

\begin{tabular}{lllr}
\hline \hline F-statistic & 0.915833 & Prob. F(9,12) & 0.5427 \\
Obs*R-squared & 8.958132 & Prob. Chi-Square(9) & 0.4411 \\
Scaled explained SS & 2.073760 & Prob. Chi-Square(9) & 0.9902 \\
\hline \hline
\end{tabular}

Test Equation:

Dependent Variable: RESID ${ }^{\wedge} 2$

Method: Least Squares

Date: 12/07/17 Time: 13:14

Sample: 19952016

Included observations: 22

\begin{tabular}{ccccc}
\hline \hline Variable & Coefficient & Std. Error & t-Statistic & Prob. \\
\hline \hline C & 90.92868 & 38.22486 & 2.378784 & 0.0348 \\
RAGDP & 0.034906 & 0.089863 & 0.388437 & 0.7045 \\
LOG(EXPT) & 11.27611 & 6.860821 & 1.643552 & 0.1262 \\
LOG(IMPT) & 2.876010 & 6.422118 & 0.447829 & 0.6623 \\
LOG(FDI(-1)) & 0.926338 & 1.967800 & 0.470748 & 0.6463 \\
LOG(GDPCBP) & -13.11214 & 5.901353 & -2.221887 & 0.0463 \\
LOG(INFRAT) & -1.852324 & 1.106194 & -1.674502 & 0.1199 \\
D(EXCRAT) & 0.005394 & 0.007353 & 0.733532 & 0.4773 \\
D(OPNSS) & -0.113616 & 0.065133 & -1.744374 & 0.1066 \\
RGDP(-1) & -0.209110 & 0.308612 & -0.677581 & 0.5109 \\
\hline \hline & 0.407188 & Mean dependent var & & 1.841204 \\
R-squared & -0.037421 & S.D. dependent var & & 2.350880 \\
Adjusted R-squared & 2.394463 & Akaike info criterion & & 4.887150 \\
S.E. of regression & 68.80143 & Schwarz criterion & & 5.383078 \\
Sum squared resid & -43.75865 & Hannan-Quinn criter. & & 5.003976 \\
Log likelihood & 0.915833 & Durbin-Watson stat & & 2.979371 \\
F-statistic & 0.542713 & & \\
Prob(F-statistic) & & & \\
\hline \hline
\end{tabular}

